supposed benefits of choices against the real costs. It helps them improve their decision-making skills by considering and testing alternative solutions to everyday problems. Through activity and guided analysis, it provides them with the means to seek informed solutions to traditional, ill-considered or politically correct answers to ageold dilemmas and avoid (or minimise) the unintended consequences of decisionmaking.

Finally, Making Choices encourages students to examine their own individual behaviour as members of a family, a community and a country. Rather than making automatic responses, or poorly-informed decisions, the program may help them discover that they have the power and intelligence to make wise choices and influence their own future.

\title{
References
}

Doig, B. et al. (1993), Conceptual Understanding in Social Education, ACER, Melbourne (Research Monograph \#45).

Joint Council on Economic Education (1989), Economics: What and When: Scope and Sequence Guidelines K-12, New York.

Peter McGregor is Director of the Melbourne-based Centre for Economic Education.

\section{How Much Spending? The EPAC Survey of Public Expenditure Preferences in Australia}

\author{
James Cox
}

I

n October 1994 the Economic Planning Advisory Commission (EPAC) published the results of an opinion survey on public spending preferences in Australia (Withers et al., 1994). Some of the press reports at the time (such as that in The Australian Financial Review, 31 October 1994) suggested that the study showed that the public is willing to pay more in taxes to finance higher levels of government spending. The authors' own summary is more accurate: 'It is found that the broad level of public expenditure is in line with taxpayers' wishes in Australia. However, there is also evidence that, on average, taxpayers might prefer some rearrangement of the composition of our public outlays' (p.ii). The study therefore supports continuation of the status quo rather than a large increase or decrease in taxation. 
Chapter 1 reviews the growth in government spending (yet again) and draws comparisons with other countries. It concludes sensibly that only a limited amount can be learned from such comparisons. Chapter 2 reviews Australian budgetary practices. This chapter finds that 'The voice of the general public is not a cohesive voice on many issues. Also, interest groups and bureaucrats have more access and influence on the budget process than the broad citizenry. Final budget preparation has inevitably been dominated by Cabinets and their committees' (p.27).

\section{The AGB McNair Survey}

The main contribution of the paper, however, is found in Chapter 3, which reports on a survey that was designed by the authors and carried out, using a random sample of 600 respondents across Australia, by AGB McNair in November-December 1992. The questionnaire is helpfully reproduced as an appendix to the paper.

The survey was a thorough one. Respondents were asked to base their opinions on a good deal of information about the level and composition of public spending. Efforts were made to correct the weaknesses that had been observed in similar previous studies; for example, respondents were at one stage reminded of the amount they pay in taxation. They were required to add the preferred amounts spent on different public services to a total that was acceptable to them. Answers to questions about the value of particular public services were cross-checked against respondents' actual use of these services. Some respondents were asked to indicate their preferences for varying levels of public spending on the assumption that 'if the total of all the amounts you decide on adds up to more or less than the amount you currently pay, your own taxes would increase or decrease accordingly' (p.73).

Two sets of results are presented. The first set reports on preferences for public expenditure when respondents are not reminded of the amount that they are already paying in tax: respondents were invited to respond to the relevant question on the supposition that 'if you recommend an increase in spending, the volume or quality of the services provided would rise, and vice versa for a decrease in spending' (p.72). Around 80 per cent of respondents would be prepared to pay some additional taxes, provided other taxpayers did likewise. Most of these respondents were prepared to pay 'a little more' rather than 'whatever was required' (p.32).

Respondents changed their views to some extent when they were confronted with the amounts they pay in tax. The preferred tax liability remained much the same as at present in these circumstances (down by less than half of one per cent), but the respondents favoured a substantial rearrangement of expenditure, in particular increased spending on environmental outlays, roads, education, police, retraining and sport and recreation. They also favoured reduced spending on general government administration and defence. Finally, the stated willingness to pay for increased public spending was less for those respondents who were 'liable to pay' the resulting increase in taxation than for those who were not so liable. 


\section{Interpreting the Results}

One great advantage of competitive markets is that customers are able to decide both the amount and the quality of each good and service that they wish to purchase. Market choice is not possible for public goods (such as many aspects of environmental quality) where the same service has to be provided to all users, or for services that are free of charge at the point of consumption. The amount and quality of these goods and services must be decided by other means. It might be argued that governments are elected to decide these things. This is true, but governments would undoubtedly be helped by reliable information about the public's willingness to pay for currently unpriced goods and services. There seems, moreover, to be an increasing tendency for governments to delegate some of the very hard decisions to more or less independent bodies.

There is little doubt, then, that a study of the kind that was undertaken by EPAC can potentially provide very useful information. Nor is there any doubt that the EPAC study is a good example of its type. Economists, however, have traditionally been sceptical about expressions of opinion: 'you should look at what people do and not at what they say they do'. It is unfortunately not possible to confirm or refute the survey responses by reference to observed behaviour. Should the survey results be compared, for example, with votes at the next election for political parties that favour higher or lower spending? Even if such a clear-cut choice were available, voting decisions are likely to be influenced by many factors in addition to views about government expenditure.

Do the results of the EPAC study, then, provide a sufficiently reliable basis for policy decisions? A number of points can be made. First, the results require careful interpretation. They arise from a survey of adults rather than taxpayers; and many adults pay little or no tax. The results should not necessarily be taken to imply that taxpayers are happy to pay their current level of taxation. It is reported that willingness to pay is highly sensitive to income levels. Moreover, 'an underrepresentation of high income eamers . . . would bias average responses upwards' (p.37). This statement is not very clear, but suggests that willingness to pay for increased spending is least among the higher-income groups who pay most tax. More information about the willingness of subgroups in the population to pay would be helpful.

Second, respondents were asked, in effect, to consider marginal adjustments to the present pattern of government expenditure. They were not reminded of the possibility of major changes to government spending and taxation such as Sir Roger Douglas (1993) has proposed in New Zealand. Under Douglas's proposals, families would be given the option of assuming greater responsibility for education and health care in return for lower levels of taxation. This may well be attractive to some groups of the population.

Third, there is the question of what respondents think they are doing when they respond to such questionnaires. They know that the government benefits they receive and the taxes they pay will not really change as a result of their answers. Do they conscientiously inquire into their preferences regarding government spending 
and taxation, or do they simply take the opportunity to express support for a good cause at no cost to themselves? It is noteworthy that respondents wished to increase spending on popular items such as the environment and sport and recreation, and to reduce it on unpopular items such as defence and public administration. These opinions could well change if respondents became aware of the difficulties in reducing the unpopular items, and were then faced with the need for increased taxation if spending on the popular items were to be increased. And their opinions might change yet again were they actually required to pay more tax.

Another approach is to examine whether the results are internally consistent. My examination of the EPAC study on this point is not entirely reassuring. For example, only 40 per cent of respondents thought that spending on retraining provided a reasonable amount or a lot of benefit to the community (p.31). But 59 per cent though that government outlays on retraining should increase (p.32). A reason for this apparent contradiction is that the question about the amount the recipients were prepared to pay for retraining followed a similar question for unemployment benefit. Respondents indicated their dislike of unemployment benefit by wishing to decrease spending on it (by 13 per cent on average). Not wishing to appear mean to the unemployed, respondents then supported increased spending on training, which many of them considered to be ineffective. If the questions had been differently ordered, the answers might have been different too.

\section{Conclusion}

I am not persuaded that studies such as the one carried out by EPAC provide reliable information to policy-makers. Nevertheless, the study raises the very important issue of transparency. . To be able to decide on the merits of increased government spending, people need to know the extent of the additional costs, now and in the future, that need to be financed by taxation and borrowing. Accurate information is not always available. Indeed, an important objective of New Zealand's recent fiscal responsibility legislation is to encourage better information about the longer-term consequences of fiscal policy (Scott, 1995). Even though it is still far from clear how the willingness of the public to pay for government spending can best be assessed, better information about the consequences of fiscal policy is the key to better debate about these issues and perhaps, ultimately, better decisions.

\section{References}

Douglas, R. (1993), Unfinished Business, Random House, Auckland.

Scott, G. (1995), 'New Zealand's Fiscal Responsibility Act', Agenda 2(1): 3-16.

Withers, G., D. Throsby \& K. Johnston (1994), Public Expenditure in Australia, EPAC, Canberra (Commission Paper No. 3).

James Cox is Principal Adviser to the NSW Government Pricing Tribunal. 